\title{
PENGGUNAAN METODE PEMBELAJARAN ROLE PLAYING \\ DALAM MENINGKATKAN KEMAMPUAN BERHITUNG PENJUMLAHAN DAN PENGURANGAN PADA SISWA KELAS VI SLB C1 DHARMA MULIA SEMARANG
}

\author{
Sri Lestari Wahyuningsih \\ Sekolah Luar Biasa C/C1 Dharma Mulia Semarang
}

\begin{abstract}
Abstrak
Hasil pengamatan sementara yang dilakukan di SLB C1, khususnya pada anak kelas VI SLB C1 Dharma Mulia Semarang, secara umum siswa memiliki kemampuan berhitung penjumlahan dan pengurangan rendah. Kondisi tersebut menggambarkan rendahnya perkembangan rendahnya perkembangan kognitif siswa SLB C1 Dharma Mulia Semarang.

Penelitian ini adalah penelitian tindakan kelas dengan menggunakan model pembelajaran role playing pada mata pelajaran Matematika yaitu berhitung penjumlahan dan pengurangan.

Kondisi Awal diperoleh ketuntasan klasikal 3/4 x 100\% = 75\% hanya mencapai $25 \%$ yang dapat mencapai ketuntasan atau sebesar $75 \%$ belum tuntas. Siklus I diperoleh ketuntasan klasikal yang mampu dicapai siswa 2/4 x 100\%= $50 \%$, yaitu sebanyak 50\% siswa mencapai ketuntasan, masih menunjukkan nilai lebih rendah dari ketetapan ketuntasan klasikal, yaitu 100\%. Siklus II diperoleh ketuntasan klasikal 100\% siswa kelas VI SLB C/C1 Dharma Mulia Semarang dapat mencapai ketuntasan. Sehingga penggunaan metode pembelajaran role playing dengan yang tepat dapat meningkatkan hasil belajar siswa kelas V SLB C1/C1 Dharma Mulia Semarang pada mata pelajaran Matematika.
\end{abstract}

Kata Kunci : Role playing, kemampuan berhitung, SLB Dharma Mulia kelas V 


\section{PENDAHULUAN}

Pendidikan adalah hal yang penting dantidak dapat dipisahkan dari kehidupan. Pendidikan tidak hanya bertindak sebagai alat yang dapat meningkatkan kapasitas kemampuan seorang anak, tetapi juga menjadi alat untuk memenuhi kebutuhan manusia. Pendidikan merupakan seni mengajar, karena dengan mengajarkan ilmu, ketrampilan dan pengalaman tertentu, orang melakukan perbuatan yang kreatif mirip dengan karya seni (Kartono, 1997). Menurut pasal 15 dalam Undang-Undang Sistem Pendidikan Nasional Tahun 2003, pendidikan terdiri dari beberapa jenis, yaitu pendididkan umu, kejuruan, akademik, profesi, vokasi, keagamaan dan khusus. Pendidikan Khusus merupakan merupakan pendidikan bagi peserta didik yang yang memiliki kesulitan dalam mengikuti proses pembelajaran karena kelainan fisik, emosional,, mental, intelektual, sosial, dan/atau memiliki potensi kecerdasan dan bakat istimewa (Undang-Undang Sistem Pendidikan Nasional Tahun 2003). Selain itu, pendidikan khusus atau pendidikan luar biasa adalah bagian terpadu dari sistem pendidikan nasional yang secara khusus diselenggarakan bagi peserta didik yang menyandang kelainan fisik dan/atau mental dan/atau kelainan perilaku. Pada umumnya pendidikan luar biasa diselenggarakan di Sekolah Luar Biasa (SLB) Mangungsong, (1998).

Seperti halnya SLB (Sekolah Luar Biasa) C Dharma Mulia Semarang, yang mana sekolah ini merupakan sekolah yang mendidik siswa berkebutuhan khusus (tuna grahita) debil dan embisil . Siswa tunagrahita sedang biasanya mempunyai masalah dengan kemampuan berbicara, yaitu artikulasi. Kesalahan artikulasi mencakup: penggantian (subtitution) bunyi, penghilangan (omission) bunyi, penambahan (addition) bunyi, dan penyimpangan bunyi. Siswa tunagrahita sedang juga mengalami perkembangan bahasa yang terlambat dan kosakata yang dimiliki sangat terbatas. Bagi siswa down sindrome kebanyakan mengalami infeksi saluran tengah pada telinganya ketika mereka masih bayi. Kehilangan pendengaran karena infeksi ini juga berpengaruh pada kemampuan berbicara anak tunagrahita. Menyadari adanya keterlambatan berbicara dan perkembangan bahasa bagi penyandang tunagrahita. Penting kiranya memberi latihan untuk 
mengembangkan kemampuan bicara. Hal ini dikarenakan pentingnya interaksi sosial, bahasa dan komunikasi dalam mendorong perkembangan kognitif.

Hasil pengamatan sementara yang dilakukan di SLB C1, khususnya pada anak kelas VI SLB C1 Dharma Mulia Semarang, secara umum siswa memiliki kemampuan berhitung penjumlahan dan pengurangan rendah. Kondisi tersebut menggambarkan rendahnya perkembangan rendahnya perkembangan kognitif siswa SLB C1 Dharma Mulia Semarang. Rendahnya kempuan berhitung siswa SLB C1 tersebut kemungkinan disebabkan oleh beberapa faktor, yaitu : kurangnya antusiasme siswa untuk belajar berhitung (khususnya pada pelajaran Matematika), media pembelajaran yang digunakan guru dalam penyampaian materi kurang menarik sehingga anak kurang semangat dalam belajar.

Ruseffendi (1992) berpendapat bahwa pada dasarnya matematika dapat dianggap sebagai studi tentang struktur, memisah-misahkan hubungan-hubungan di antara struktur-struktur dan mengkategorikan hubungan-hubungan di antara struktur-struktur. Seperti halnya dengan Bruner, Dienes mengemukakan bahwa tiap-tiap konsep atau prinsip dalam matematika yang disajikan dalam bentuk yang konkret akan dapat dipahami dengan baik. Ini mengandung arti bahwa jika bendabenda atau objek-objek dalm bentuk permainan akan sangat berperan bila dimanipulasi dengan baik dalam pengajaran matematika. Perkembangan konsep matematika dapat dicapai melalui pola berkelanjutan, yang setiap seri dalam rangkaian kegiatan belajar dari kongkret ke simbolik. Tahap belajar adalah interaksi yang direncanakan antara yang satu segmen struktur pengetahuan dan belajar aktif, yang dilakukan melalui media matematika yang desain secara khusus.

Permainan matematika sangat penting sebab operasi matematika dalam permainan tersebut menunjukan aturan secara kongkret dan lebih membimbing dan menajamkan pengertian matematika pada anak didik. Dapat dikatakan bahwa objek-objek kongkret dalam bentuk permainan mempunyai peranan sangat penting dalam pembelajaran matematika jika manipulasi dengan baik. Menurut Reseffendi (1992:125-127) konsep-konsep matematika akan berhasil jika dipelajari dalam tahap-tahap tertentu. Berangkat dari hambatan yang dihadapi 
siswa tunagrahita tersebut, diperlukan suatu model pembelajaran yang mampu merangsang tiga komponen utama perhatian, yaitu : attention span, focus, dan selective anttetion dalam pembelajaran berhituing, yaitu model pembelajaran yang melibatkan siswa dalam suatu permainan sehingga ketiga focus utama perhatian mereka akan terangsang.

Model pembelajaran role playing menuntut prestasi dalam pembelajaran. Dikaitkan dengan pembelajaran berhitung penjumlahan dan pengurangan, model role playing bisa dimainkan dengan permainan jual beli di mana siswa berperan sebagai penjual dan pembeli dalam operasi hitung yang diajarkan. Model pembelajaran role playing merupakan model pembelajaran yang menarik yang kemungkinan dalam merangsang siswa untuk lebih antusias dalam mengikuti kegiatan pembelajaran, khususnya pelajaran Matematika yaitu berhitung penjumlahan dan pengurangan. Tujuan penerapan model pembelajaran role playing adalah untuk mengajak siswa lebih aktif melakukan interaksi dengan teman atau guru dengan suatu permainan peran. Yang mana dalam permainan tersebut guru akan memasukkan unsur belajar berhitung penjumlahan dan pengurangan, sehingga dengan permainan tersebut siswa tidak jenuh untuk belajar berhitung penjumlahan dan pengurangan

\section{METODE PENELITIAN}

\section{Desain Penelitian}

Mengacu pada tujuan dalam penelitian ini, yaitu peningkatan kualitas pembelajaran berhitung, maka jenis penelitian yang digunakan adalah penelitian tindakan kelas (Classroom Action Research). Penelitian tindakan kelas menurut pendapat Elliott (2001:1) disebutkan sebagai proses di mana guru bekerjasama dalam mengecaluasi pelaksanaan tugas mengajar yang dilakukan dengan tujuan meningkatkan kualits pembelajaran.

Berdasarkan pendapat Elliott, dikatakan bahwa penelitian tindakan kelas merupakan proses di mana hal ini sejalan dengan pendapat Kemmis yang dikutip oleh Wiriaatmadja (2006:64) yang mengatakan bahwa "penelitian tindakan kelas verorientasi pada peningkatan kualitas pembelajaran”. 
Proses siklus kegiatan dalam penelitian tindakan kelas menurut Kemmis dan Taggart (Wiriaatmadja, 2006:65) dapat digambarkan ke dalam bagan skematis sebagai berikut.

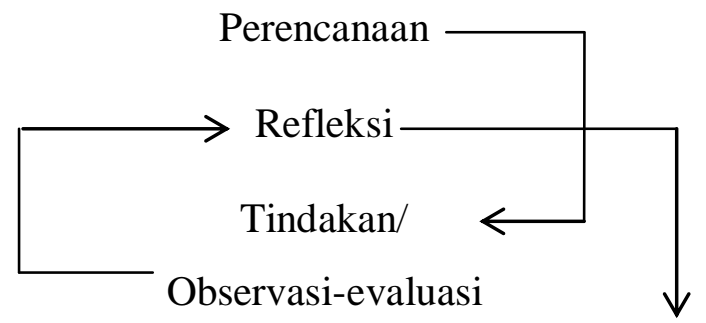

Perbaikan Rencana

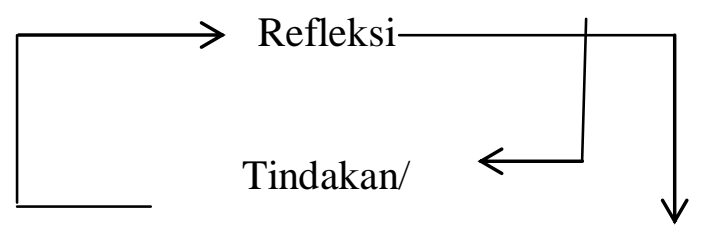

Observasi-evaluasi

Perbaikan Rencana

Sumber: Wiriaatmadja (2006:65)

Gambar 2. Siklus Aktivitas dalam Penelitian Tindakan Kelas

Desain penelitian tindakan kelas yang dinilai akurat dalam mencapai tujuan tersebut adalah model desain alur dari Kemmis dan taggart (Wiriaatmadja, 2006:65) yang memiliki ciri khas menggunakan model siklus. Setiap siklus terdiri dari dua atau tiga tindakan pembelajaran, sedangkan setiap tindakan pembelajaran mencakup empat tahapan kegiatan, yaitu perencanaan, pelaksanaan tindakan, observasi, dan refleksievaluasi.

Tempat Penelitian dan Waktu Penelitian

Penelitian dilakukan di kelas VI SLB C1 Dharma Mulia Semarang tahun pelajaran 2015/2016. 


\begin{tabular}{|c|c|l|c|l|}
\hline No. & Mata Pelajaran & \multicolumn{1}{|c|}{ Hari/Tanggal } & Waktu & Perbaikan \\
\hline \multirow{2}{*}{ Matematika } & $\begin{array}{l}\text { Jumat,11 } \\
\text { September 2015 }\end{array}$ & $7.30-09.00$ & Siklus I \\
\cline { 3 - 5 } & $\begin{array}{l}\text { Jumat,18 } \\
\text { September 2015 }\end{array}$ & $7.30-09.00$ & Siklus II \\
\hline
\end{tabular}

Subjek Penelitian

Subjek penelitian adalah siswa kelas VI SLB C/C1 Dharma Mulia Semarang tahun pelajaran 2015/2016. Jumlah siswa kelas VI SLB C/C1 Dharma Mulia Semarang tahun pelajaran 2015/2016 adalah sebanyak 4 orang siswa.

\section{HASIL PENELITIAN DAN PEMBAHASAN}

Hasil Penelitian

Data yang ingin peneliti sajikan pada penelitian penyusunan laporan penelitian tindakan kelas atau PTK tentang penggunaan metode pembelajaran role playing unutk meningkatkan kemampuan berhitung penjumnlahan dan pengurangan pada siswa kelas VI C1 SLB Dharma Mulia Semarang. Sebelum peneliti melakukan perbaikan pembelajaran. Adapun data awal atau kondisi awal dengan melakui teknik dokumentasi, peneliti memperoleh data awal sebagai berikut:

Kondisi Awal

\begin{tabular}{|l|l|l|l|}
\hline No & Nama & Nilai & Keterangan \\
\hline 1 & Karis & 55 & Belum Tuntas \\
\hline 2 & Gunawan & 50 & Belum Tuntas \\
\hline 3 & Vita & 65 & Tuntas \\
\hline 4 & Faris & 50 & Belum Tuntas \\
\hline & & & \\
\hline
\end{tabular}




\begin{tabular}{|l|l|l|}
\hline Rata-rata & 55 & \\
\hline Ketuntasan Klasikal (\%) & 75 & Belum Tuntas \\
\hline
\end{tabular}

dilihat dari ketuntasan klasikal 3/4 x 100\% = 75\% hanya mencapai 25\% yang dapat mencapai ketuntasan atau sebesar $75 \%$ belum tuntas.

Siklus 1

1) Perencanaan

Perencanaan sebagai tindakan persiapan dalam dalam penyusunan laporan penelitian tindakan kelas atau PTK tentang penggunaan metode pembelajaran role playing untuk meningkatkan kemampuan berhituung penjumlahan dan pengurangan pada siswa kelas VI SLB C1 Dharma Mulia yaitu sebagai berikut:

a. Mentyusun scenario pembelajaran konstektual dengan strategi model role playing

b. Mempersiapkan nsarana dan prasarana pembelajaran, mengatur letak meja belajar untuk mendukung kehgiatan interaktif, buku sumber rujukanyang relevan, papan tulis, media pembelajaran berupa uang daqn prangkap pendukung lainya seperti: komoditi perdagangan

c. Mempersiapkan instrument observasi untuk mengamati perilaku guru dalam proses pembelajaran, aktifitas kelas saat berlangsungnya proses pembelajaran dan perilaku siswa selama berlangsungnya prposes pembelajaran dan setelah berlangsungnya proses pembelajaran

d. Melakukan simulasi pelaksanaan tindakan, dan mgnuji keterlaksanaanya dilapangan.

2) Pelaksanaan

Kegiatan yangdilakukan yaitu:

a. Siswa diberi tugas mandiri yaitu: 
- mengerjakan soal perhitungan

- memberikan penjelasan tentang proses pembelajaran yang akan dilakuykan dan tujuan yang akan dicapai.

- Melakukan proses pretest dengan alokasi waktu 10 menit.

- Siswa melakukan permainan peranan sebagai penjual dan pembeli.

- Memberikan komoditio brang dagangan kepada siswa yang berperan sebagai penjual lengkap dengan harga-harga setiap komoditi tersebut.

- Memberikan uang sebagai siswa yang berperan sebagai pembeli untuk melakukan transaksi pembelian komoditi sesuai dengan soal cerita yang sudah dipersiapkan sebelumnya.

Berdasarkan permainan jual beli tersebut siswa melakukan operasi hitung penjumlahan dan pengurangan. Bertindak sebagai fasilitator dan melakukan observasi aktifitas kelas dan perilaku siswa selama berlangsungnya proses pembelajaran. Berdasarkan kegiatan yang telah dil;akuykan maka dapat disajikan hasil tes siklus 1 baik dalam table maupun dalam grafik sebagai berikut:

\section{Hasil siklus I}

Ketuntasan klasikal yang mampu dicapai siswa $2 / 4 \times 100 \%=50 \%$, yaitu sebanyak 50\% siswa mencapai ketuntasan, masih menunjukkan nilai lebih rendah dari ketetapan ketuntasan klasikal, yaitu $100 \%$.

Pelaksanaan siklus I yaitu pembelajaran role playing, pencapaian kemampuan berhitung penjumlahan dan pengurangan pada mata pelajaran Matematika belum mencapai hasil sesuai yang diharapan. Untuk lebih jeklasnya dapat dilihat dalam grafik dibawah ini 


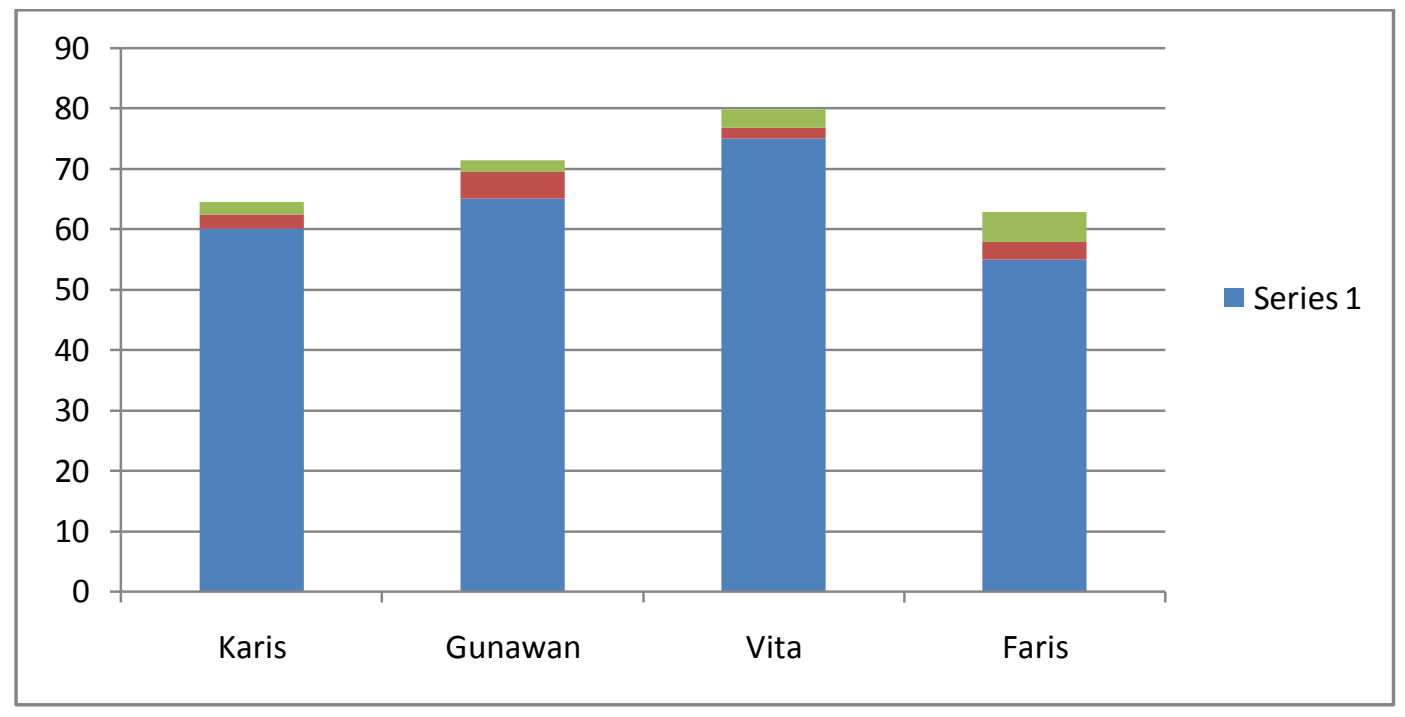

\section{3) Observasi}

Hasil observasi yang didapatkan pada hasil siklus 1 adalah rata-rata siswa belum aktif memperhatikan pembelajaran, dan belum mantab dalam menggunakan alat peraga

4) Refleksi

Berdasarkan data awal dan data hasil siklus 1 , maka dapat dipahami seberapa jauh hasil perbaikan pembelajaran dengan memperhatikan kelemahan yang ada yaitu siswa belum bisa aktif memperhatikan kegiatan pembelajaran dan belum mantap menggunakan alat peraga, sedangkjkan kelebihan yang ada terdapat siswa bisa aktif dan menggunakan alat peraga

\section{Siklus II}

1) Perencanaan

Perencanaan sebagai tindakan persiapan dalam dalam penyusunan laporan penelitian tindakan kelas atau PTK tentang penggunaan metode pembelajaran role playing untuk meningkatkan kemampuan berhituung penjumlahan dan pengurangan pada siswa kelas VI SLB C1 Dharma Mulia yaitu sebagai berikut: 
e. Mentyusun scenario pembelajaran konstektual dengan strategi model role playing

f. Mempersiapkan nsarana dan prasarana pembelajaran, mengatur letak meja belajar untuk mendukung kehgiatan interaktif, buku sumber rujukanyang relevan, papan tulis, media pembelajaran berupa uang daqn prangkap pendukung lainya seperti: komoditi perdagangan

g. Mempersiapkan instrument observasi untuk mengamati perilaku guru dalam proses pembelajaran, aktifitas kelas saat berlangsungnya proses pembelajaran dan perilaku siswa selama berlangsungnya prposes pembelajaran dan setelah berlangsungnya proses pembelajaran

h. Melakukan simulasi pelaksanaan tindakan, dan mgnuji keterlaksanaanya dilapangan.

\section{2) Pelaksanaan}

Kegiatan yangdilakukan yaitu:

b. Siswa diberi tugas mandiri yaitu:

- mengerjakan soal perhitungan

- memberikan penjelasan tentang proses pembelajaran yang akan dilakuykan dan tujuan yang akan dicapai.

- Melakukan proses pretest dengan alokasi waktu 10 menit.

- Siswa melakukan permainan peranan sebagai penjual dan pembeli.

- Memberikan komoditio brang dagangan kepada siswa yang berperan sebagai penjual lengkap dengan harga-harga setiap komoditi tersebut.

- Memberikan uang sebagai siswa yang berperan sebagai pembeli untuk melakukan transaksi pembelian komoditi sesuai dengan soal cerita yang sudah dipersiapkan sebelumnya. 
Berdasarkan permainan jual beli tersebut siswa melakukan operasi hitung penjumlahan dan pengurangan. Bertindak sebagai fasilitator dan melakukan observasi aktifitas kelas dan perilaku siswa selama berlangsungnya proses pembelajaran. Berdasarkan kegiatan yang telah dil;akuykan maka dapat disajikan hasil tes siklus II baik dalam tabel maupun dalam grafik sebagai berikut:

Ketuntasan klasikal 100\% siswa kelas VI SLB C/C1 Dharma Mulia Semarang dapat mencapai ketuntasan.

Sehingga dapat disimpulkan bahwa pelaksanaan pembelajaran dengan role playing mampu meningkatkan kemampuan berhitung penjumlahan dan pengurangan pada siswa kelas VI SLB C/C1 Dharma Mulia Semarang

Selanjutnya pada perbaikan pembelajaran siklus II nilai rata-rata yang diperoleh mencapai 78,75 suasana proses pada siklus II tampak lebih hidup dan bermakna. Siswa sangat aktif ketika mengikuti proses pembelajaran dengan metode role playing. Metode role playing yang dipilih dan digunakan peneliti ternyata mampu meningkatkan keaktifan siswa dan meningkatkan hasil belajar per siklus dan membuat proses pembelajaran lebih efesien.

.Untuk lebih jelasnya dapat dilihat dalam grafik dibawah ini:

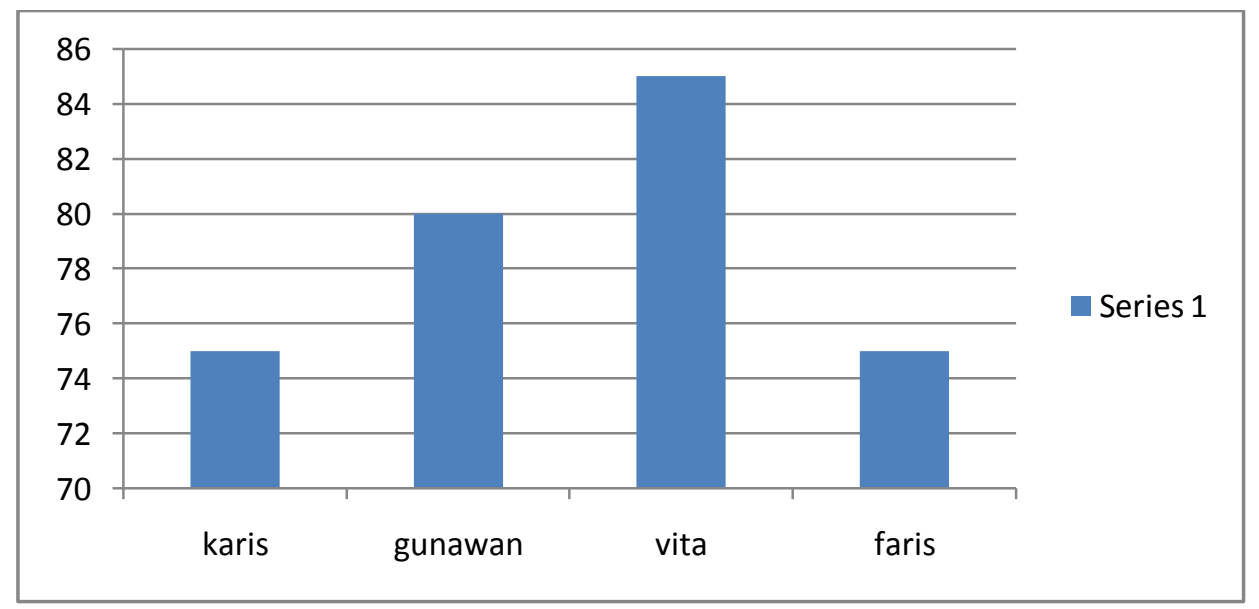


Selanjutnya pada perbaikan pembelajaran siklus II, nilai rata-rata yang diperoleh siswa mencapai 78,75. Suasana proses pembelajaran pada siklus II ini tampak lebih hidup dan lebih bermakna. Siswa sangat aktif ketika mengikuti proses pembelajaran dengan menggunakan metode pembelajaran role playing.

Metode pembelajaran role playing yang dipilih dan digunakan Peneliti ternyata mampu meningkatkan keaktifan siswa dan meningkatkan hasil belajar per siklus dan membuat proses pembelajaran lebih efisien.

3) Observasi

Hasil observasi yang didapatkan siklus II adalah rata-rata siswa aktif , memperhqatikan pembelajaran dan mantab dalam menggunakan alat peraga.

4) Refleksi

Refleksi berdasarkan data awal dan data sikuls II , maka dapat dipahami seberapa jauh hasil perbaikan pembelajaran dengan memperhatikan kelemahan yang ada pada siklus I dapat dieleminir yang baik sehingga siswa aktif memperhatikan. Kegiatan pembelajarann dan mantab menggunakan alat peraga dan didapatkan hasil semua siswa nailai ketuntasan klasikal dapat dipenuhi yaitu 4 siswa yaitu tuntas semua.

Pembahasan Per Siklus

Dalam melaksanakan kegiatan belajar mengajar guru harus dapat meningkatkan aktifitas belajar siswa dengan cara menciptakan lingkungan belajar yang lebih baik, mampu membelajarkan dan membantu siswa mencapai tujuan belajar, menyediakan sumber belajar dan media pembelajaran yang sesuai, menentukan metode/strategi pembelajaran yang efektif, serta tidak mendominasi pembelajaran yang diakukannya.

Berdasarkan temuan data yang diperoleh dari proses perbaikan pembelajaran yang dilaksanakan tiap siklus terbukti menunjukkan adanya perubahan hasil belajar siswa yang meningkat. dalam pembelajaran didukung oleh pemilihan metode yang relevan ternyata memberikan hasil yang cukup baik. Hal 
ini terbukti dari hasil kemajuan yang dialami oleh masing-masing siswa yang semakin meningkat pada tiap siklus perbaikan pembelajaran.

Temuan yang diperoleh melalui perbaikan pembelajaran pada mata pelajaran Matematika, diolah dan disajikan dalam bentuk data agar memperoleh gambaran yang konkrit, jelas, dan rinci dari hasil PTK yang dilaksanakan. Data tersebut merupakan nilai siswa yang diambil melalui evaluasi secara individual pada saat proses pembelajaran.

Hasil pengamatan/observasi yang dilakukan teman sejawat pada siklus I, II,untuk mata pelajaran Matematika dalam penelitian ini dikelompokkan menjadi dua data yaitu: data primer dan data sekunder. Data primer meliputi semua data hasil observasi yang dilakukan teman sejawat dan hasil refleksi Peneliti sendiri, sedangkan data sekunder meliputi semua nilai hasil belajar yang diperoleh dari tes akhir dan lembar observasi keaktifan siswa.

Tabel 4.4. Rekapitulasi hasil belajar siswa siklus I, II Matematika

\begin{tabular}{|c|l|l|l|l|}
\hline \multirow{2}{*}{ No } & \multicolumn{2}{|c|}{$\begin{array}{c}\text { Rata-rata Hasil Belajar } \\
\text { Persiklus }\end{array}$} & Jumlah & $\begin{array}{c}\text { Rata-rata } \\
\text { Siklus }\end{array}$ \\
\cline { 2 - 3 } & Siklus I & Siklus II & & \\
\hline 1 & 63,75 & 78,75 & 142,50 & 71,25 \\
\hline
\end{tabular}

Dari rekapitulasi hasil belajar siswa pada perbaikan pembelajaran Matematika tampak jelas perbandingan keberhasilan siswa dalam perbaikan pembelajaran setiap siklusnya.

\section{KESIMPULAN}

Kesimpulan yang diperoleh dari kegiatan perbaikan pembelajaran mata pelajaran Matematika dengan menggunakan metode pembelajaran role playing adalah penggunaan metode pembelajaran role playing dengan yang tepat dapat meningkatkan hasil belajar siswa kelas V SLB C1/C1 Dharma Mulia Semarang pada mata pelajaran Matematika . 


\section{DAFTAR PUSTAKA}

Blatner, A. (2002). Role Playing in Education. [on line]. Tersedia: http://www.Blatner.com/adam/papers.html. diakses pada 18 Maret 2015

Elliot, John. (2001). Classroom Action Research. Article. http://www.madison.edu diakses pada 25 April 2015.

Hamalik, Oemar. (2001). Proses Belajar Mengajar, Jakarta: Bumi Aksara

Jack, H. (2002). Mental Retardation: Update 2002. Tersedia: http://www.ericdigests.org/2003-4/. Diakses pada 12 september 2015

Kartono, Kartini. (1997). Psikologi Anak. Edisi Revisi. Bandung : Alumni

Mangunsong, dkk. (1998). Psikologi dan Pendidikan Anak Luar Biasa. Jakarta: LPSP3 Universitas Indonesia.

Moeslichatoen. (2004). Metode Pengajaran Di Taman Kanak-Kanak. Jakarta : PT. Asdi Mahastya

Mulyadi, S,. (2004). Bermain dan Kreativitas (Upaya Mengembangkan Kreativitas Anak Melalui Kegiatan Bermain). Jakarta: Papas Sinar Sinanti

Ruseffendi. (1992). Materi Pokok Matematika 3. Jakarta: Depdikbud.

Skjorten, M. D. (2003). Pendidikan Kebutuhan Khusus Sebuah Pengantar. Bandung: PPS UPI.

Slameto, (2005). Belajar dan Faktor-faktor yang Mempengaruhinya. Edisi Revisi. Jakarta: PT. Rineka Cipta.

Suparno, P. (2001). Teori Perkembangan Kognitif Jean Piaget. Yogyakarta: Kanisius.

Wiriaatmadja, Rochiati. (2006). Metode Penelitian Tindakan Kelas. Bandung: PT. Remaja Rosdakarya 